14.01

\title{
2D-наноуглероды как основа иммобилизованных микробных препаратов
}

\author{
(c) А.П. Возняковский,, 1 И.И. Новикова, ${ }^{2}$ А.А. Возняковский, ${ }^{3}$ И.В. Бойкова, ${ }^{2}$ А.Ю. Неверовская ${ }^{1}$ \\ ${ }^{1}$ Научно-исследовательский институт синтетического каучука им. С.В. Лебедева, \\ 198035 Санкт-Петербург, Россия \\ ${ }^{2}$ Всероссийский научно-исследовательский институт защиты растений, \\ 196608 Санкт-Петербург, Россия \\ ${ }^{3}$ Физико-технический институт им. А.Ф. Иофрфе РАН, \\ 194021 Санкт-Петербург, Россия \\ e-mail: voznap@mail.ru
}

Поступило в Редакцию 23 декабря 2019 г.

В окончательной редакции 23 декабря 2019 г.

Принято к публикации 17 февраля 2020 г.

Представлены экспериментальные данные по получению сухих порошков иммобилизованных биопрепаратов, предназначенных для очистки почвы от загрязнений нефтью и нефтепродуктами. В качестве базового метода получения $2 D$-углеродных структур, используемых в качестве подложки для иммобилизации микроорганизмов-нефтедеструкторов, выбрана методика карбонизации биополимеров (крахмала, лигнина) в условиях процесса самораспространяющегося высокотемпературного синтеза. Микроорганизмынефтедеструкторы отселектированы из аккредитованной коллекции Всероссийского института защиты растений. Полученные экспериментальные образцы биопрепаратов показали перспективность их использования для ликвидации техногенных последствий загрязнения почвы нефтепродуктами.

Ключевые слова: $2 D$-наноуглерод, карбонизация биополимеров, метод самораспространяющегося высокотемпературного синтеза, иммобилизованные биопрепараты.

DOI: 10.21883/JTF.2020.09.49674.424-19

\section{Введение}

В настоящее время биологическая наука переходит от традиционного представления о микробных клетках как строго индивидуальных организмах к представлению о микробных сообществах как целостных структурах, регулирующих свои физиолого-биохимические особенности в зависимости от изменения условий обитания. В частности, иммобилизация микробных сообществ на поверхности твердых носителей - создание иммобилизованных биопрепаратов - рассматривается как перспективное направление создания высокотехнологичных, сохраняющих долгое время свои исходные свойства биопрепаратов нового поколения. При этом существенным требованием к создаваемым биопрепаратам является возможность их получения в порошкообразном виде, что обеспечивает удобство при их хранении, транспортировке и применении. Как следствие, интенсивно исследуются композиции, представляющие собой ассоциаты микробных клеток и частиц неорганических материалов $[1,2]$.

В таких препаративных формах поверхность частицы твердого материала представляет собой подложку, на которой распределены клетки микроорганизмов или активные молекулы. В последнее время внимание многих исследовательских групп привлекают ассоциаты микроорганизмов и углеродных наноматериалов, что обуслов- лено возможностью включения углеродного компонента в биогеохимический цикл [3].

В принципе в качестве основы при создании биопрепарата может использоваться весь ряд аллотропных форм наноуглерода: наноалмазы детонационного синтеза, фуллерены, нанотрубки и графеновые материалы. К графеновым материалам в отличие от, собственно, графена относят семейство $2 D$-углеродных структуры, содержащие до 60 слоев графена [4]. Преимуществом графеновых структур является то, что при наноразмерной толщине листа или многослойного пакета листов графена площадь планарной - не удельной - поверхности графенового листа достаточно высока. Соответственно особенностями получаемой матрицы являются возможность иммобилизации на поверхности одного листа значительного количества клеток микроорганизмов и возможность формирования сэндвичевой наноуглеродклеточной структуры [5], что обеспечит высокую концентрацию клеток в малом объеме. Кроме того, специфика структуры графенового листа обеспечивает возможность формирования значительного количества физических связей клетка микроорганизма/поверхность листа. Последнее обстоятельство обусловливает возможность надежной адсорбции клеток микроорганизмов на поверхности листов графена.

Поэтому растет интерес к исследованиям, посвященным изучению функциональных особенностей клеток микроорганизмов, размещенных на поверхности $2 D$-гра- 
феновых структур [6 и ссылки в ней]. 2D-углеродные наноматериалы эффективно взаимодействуют с различными биологическими субстратами (белками, низкомолекулярными биорегуляторами, клетками микроорганизмов), что позволяет рассматривать их как основу для концентрирования и иммобилизации молекул биологически активных веществ и клеток микроорганизмов, a также эффективные средства доставки молекул к специфическим мишеням [7].

Однако, несмотря на показанную перспективу внедрения $2 D$-графеновых структур в биотехнологию, до настоящего времени они не нашли широкого практического использования. Основным препятствием, мешающим их широкому внедрению в реальную практику биотехнологии, является явно недостаточная производительность разработанных к настоящему времени методик синтеза. Даже наиболее производительные методики синтеза, такие как многочисленные варианты метода Хаммерса [8] и методики жидкофазного расслоение графита в поле ультразвука [9], позволяют получать графеновые материалы в объемах достаточных только для лабораторных экспериментов (десятки грамм в смену), но их производительности недостаточно для обеспечения реальных потребностей биотехнологии. В частности, такая материалоемкая область как создание иммобилизованных биопрепаратов для ликвидации нефтяных загрязнений, требует с учетом масштабности техногенных катастроф наличия переходящих запасов биопрепаратов в сотни килограмм.

Также необходимо отметить, что результаты разных исследовательских групп по использованию графеновых структур в биологических исследованиях носят противоречивый характер. Так, в работах, посвященных взаимодействию наиболее доступных для реального использования оксида графена и восстановленного оксида графена, описывают их явно выраженные фунгицидные свойства $[10,11]$. С другой стороны, имеются сообщения об успешном использовании в биохимических процессах, нанесенных на поверхность наноуглеродов бактериальных клеток $[12,13]$. Наблюдаемое противоречие можно связать с тем, что жизнеспособность и активность клеток микроорганизмов критически зависит от совокупности особенностей морфометрических и химических параметров графенового материала и может значительно варьироваться у разных штаммов бактерий в зависимости от их физиолого-биохимических особенностей.

Таким образом, для реализации потенциальных возможностей использования $2 D$-графеновых структур с целью создания иммобилизованных биопрепаратов необходимо предложить методику их получения, которая, кроме высокой производительности, позволяла бы получать графеновые структуры с морфометрическими параметрами, обеспечивающими длительный срок жизни иммобилизованных биообъектов. Также эта методика должна обеспечивать приемлемую для реальной прак- тики стоимость получаемого материала в рассматриваемом случае стоимости $2 D$-графеновых структур.

При планировании проведения работы было предположено, что наиболее полно этим требованием отвечает методика самораспространяющегося высокотемпературного синтеза (СВС) [14]. СВС-процесс - это экзотермический химический процесс типа горения, протекающий в автоволновом режиме в смесях порошков окислителя и восстановителя. СВС-процесс представляет собой режим протекания экзотермической реакции, в котором тепловыделение локализовано в узком слое (зона синтеза) и передается от слоя к слою путем теплопередачи. Температура в зоне синтеза может достигать $2000^{\circ}$. Основное достоинство технологии СВС заложено в самом ее принципе - в использовании выделяющегося тепла химических реакций вместо нагрева вещества от внешнего источника, что позволяет СВС процессам успешно конкурировать с традиционными энергоемкими технологиями [15].

Известно, что нативным элементом листа графена является цикл из 6 атомов углерода - гексагон. Установление источника таких циклов, а также разработка методики инициирования их „bottom-up“ процессов деструкции/самоорганизации позволило бы получать $2 D$-углеродные структуры в необходимом масштабе. Мы предположили, что приемлемым источником гексагонов могут быть биополимеры, содержащие циклические структуры в основной цепи, например, крахмал, лигнин.

Целью настоящей работы являлась разработка методики получения $2 D$-углеродных структур по своим морфометрическим параметрам, соответствующим применению в иммобилизованных биопрепаратах, предназначенных для ликвидации последствий розлива нефти и нефтепродуктов.

\section{1. Экспериментальная часть}

\section{1. Синтез $2 D$-структур}

Шихту для карбонизации приготовляли смешением окислителя (соли ряда аммония) и восстановителя (крахмал (ч.д.а.), лигнин (из отвалов длительного хранения Архангельского целлюлозно-бумажного комбината) в соотношении $1: 1$. Карбонизацию проводили на лабораторной установке, представляющей собой кварцевый стакан (1 L) с нагревательным элементом в нижней части, обеспечивающим нагрев зоны реакции до $500^{\circ} \mathrm{C}$. Даже такой объем реактора (при загрузке на треть объема) позволял получать до $100 \mathrm{~g}$ карбонизированного продукта в смену $(6 \mathrm{~h})$. При этом нет никаких принципиальных ограничений для масштабирования лабораторной установки.

\section{2. Микроорганизмы-деструкторы}

Микроорганизмы-нефтедеструкторы были выбраны из коллекции Института защиты растений (ВИЗР, 
Санкт-Петербург), имеющей государственную аккредитацию. В коллекции института хранится и поддерживается более 200 штаммов бактерий, включая актиномицеты, и грибов - деструкторов ксенобиотиков различных химических классов, принадлежащих к родам Pseudomonas, Bacillus, Rhodococcus, Acetobacter, Acinetobacter, Serratia, Burkholderia, Micrococcus, Acidovorax, Brevibacterium, Ralstonia, Alcaligenes, Streptomyces, Trichoderma.

Штаммы микроорганизмов-деструкторов ксенобиотиков выделены из техногенно загрязненных почвенных и водных экосистем в разных природно-климатических зонах. На их основе созданы стабильные ассоциации, эффективно и быстро окисляющие различные токсиканты в короткий срок в разных экологических условиях.

В состав коллекции входят штаммы, утилизирующие трудноокисляемые соединения, включая тяжелые фракции нефти и полиароматические углеводороды (бензопирен, хризен, фенантрен, антрацен, нафталин, ПХБ etc.), что позволяет составлять специфические ассоциации штаммов-деструкторов для утилизации конкретного загрязнения (Patent application No 96111982/13 accepted 11.08.1997).

Все коллекционные штаммы идентифицированы и имеют паспорта, включающие описание их морфологических, культуральных, физиолого-биохимических и молекулярно-генетических особенностей.

Для глубинного культивирования штаммов микроорганизмов была использована питательная среда следующего состава: $\mathrm{KH}_{2} \mathrm{PO}_{4}-2 \mathrm{~g}, \mathrm{NaHPO}_{4}-2 \mathrm{~g}$, $\left(\mathrm{NH}_{4}\right) \mathrm{SO}_{4}-\mathrm{g}, \mathrm{MgSO}_{4} \cdot 7 \mathrm{H}_{2} \mathrm{O}-0.5 \mathrm{~g}, \mathrm{FeCl}_{3} \cdot 6 \mathrm{H}_{2} \mathrm{O}-$ $0.01 \mathrm{~g}$, соевая мука $-5 \mathrm{~g}$, сахароза $-20 \mathrm{~g}, \mathrm{H}_{2} \mathrm{O}-11$.

Глубинное культивирование проводили в колбах Эрленмейера на круговой качалке при $28^{\circ} \mathrm{C}$ в течение $72 \mathrm{~h}$. После окончания культивирования определяли титр жизнеспособных клеток в культуральной жидкости стандартным методом серийных разведений с последующим высевом на среду сухого питательного агара (СПА) и подсчетом числа выросших колоний.

Число жизнеспособных спор (млрд) в $1 \mathrm{ml}(X)$ вычисляли по формуле $X=K /(P \cdot x \cdot y)$, где $K-$ число колоний (среднее арифметическое результатов подсчета колоний в трех чашках $), P-$ разведение $\left(10^{-7}, 10^{-8}\right.$ или $\left.10^{-9}\right) ; y-$ объем суспензии, взятой для высева $\left[\mathrm{cm}^{3}\right]$.

Для оценки влияния графена на жизнеспособность и нефтеокисляющую активность штаммов в чашку Петри помещали $0.5 \mathrm{~g}$ образца наноуглерода и постепенно добавляли $0.5 \mathrm{ml}$ культуральной жидкости при постоянном перемешивании до ее полного впитывания. Чашку Петри закрывали и оставляли при комнатной температуре на 5 суток, после чего определяли титр жизнеспособных клеток методом серийных разведений.

Для оценки влияния образцов графена на нефтеокисляющую активность штаммов микроорганизмов использовали полуколичественный метод. На поверхность голодной агаризованной среды Чапека следующего состава $[\mathrm{g} / \mathrm{l}]$ : нитрат натрия 3.0; сульфат магния 0.5; хлорид калия 0.5; сульфат железа (III) 0.01 ; фосфат калия двузамещенный 1.0; агар-агар 13.0 наносили тонким слоем нефть в качестве единственного источника углерода. После этого микробиологической петлей производили посев культур микроорганизмов на поверхность двуслойного агара. Для посева использовали культуральную жидкость штаммов, а также образцы графена в сочетании с клетками микроорганизмов. Нефтеокисляющую активность оценивали визуально через 3 суток по величине зон просветления вокруг культур, растущих на агаре с нефтепродуктами.

\section{3. Сканирующая электронная микроскопия (CЭM)}

СЭМ исследования проводились на микроскопе на приборе TESCAN Mira-3M с EDX приставкой Oxford instruments $X$-max при ускоряющем напряжении $20 \mathrm{kV}$.

\section{4. Рентгенофазовый анализ (X-RAY)}

$X$-RАY-исследования проводились на приборе XRD-7000, $\quad\left(\mathrm{Cu} K_{\alpha}\right.$-излучение,$\left.\quad \lambda=0.154051 \mathrm{~nm}\right)$ (Shimadzu, Jupan).

\section{5. Спектроскопия комбинационного рассеяния (СКР или рамановская спектроскопия)}

Для исследования качества синтезированных образцов были сняты CKР спектры на приборе horiba yobin yvon LabRam HR 800, лазер $532 \mathrm{~nm}$, дифракционная решетка 1800 lines/mm, микрораман (микроскоп, увеличение $20 \times$ ).

\section{6. Определение удельной поверхности}

Определение удельной поверхности синтезированных образцов проводилось методом полимолимолекулярной адсорбции (метод БЭТ) на приборе ASAP 2020, США. В качестве газа-адсорбата использовался азот. В качестве стандартной пробоподготовки перед измерением использовался прогрев в вакууме при температуре $300^{\circ} \mathrm{C}$ в течение $3 \mathrm{~h}$. Погрешность измерения составляла не более $3 \%$.

\section{2. Результаты и их обсуждение}

Для исследования морфологии синтезированных методом СВС графеновых структур были проведены СЭМ исследования, результаты которых представлены на рис. 1.

Как видно из рис. 1, синтезированные из лигнина и крахмала структуры представляют из себя плоские частицы размером в несколько десятков микрон. За счет 

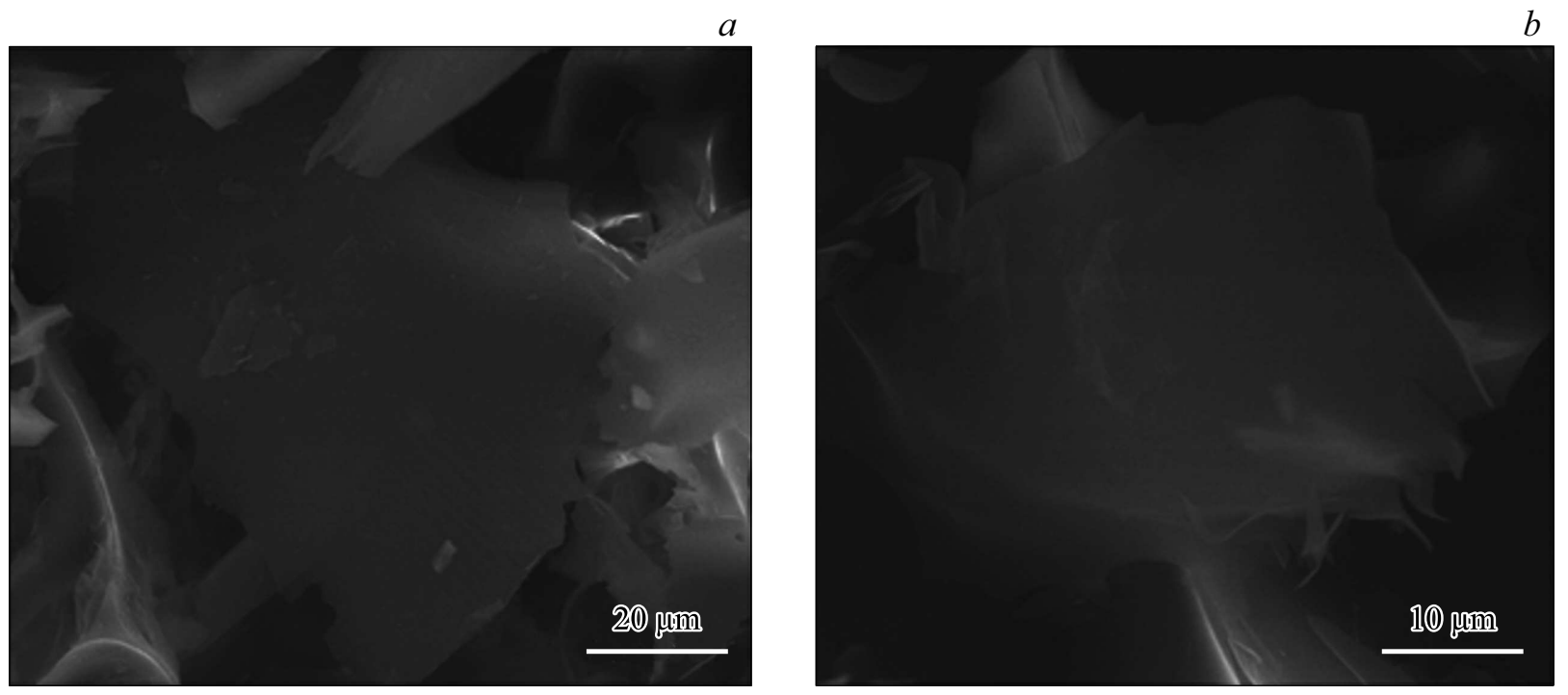

Рис. 1. Электронные микрофотографии графеновых структур, синтезированных методом СВС: $a$ - из лигнина, линейная шкала $20 \mu \mathrm{m} ; b$ - из крахмала, линейная шкала $10 \mu \mathrm{m}$.
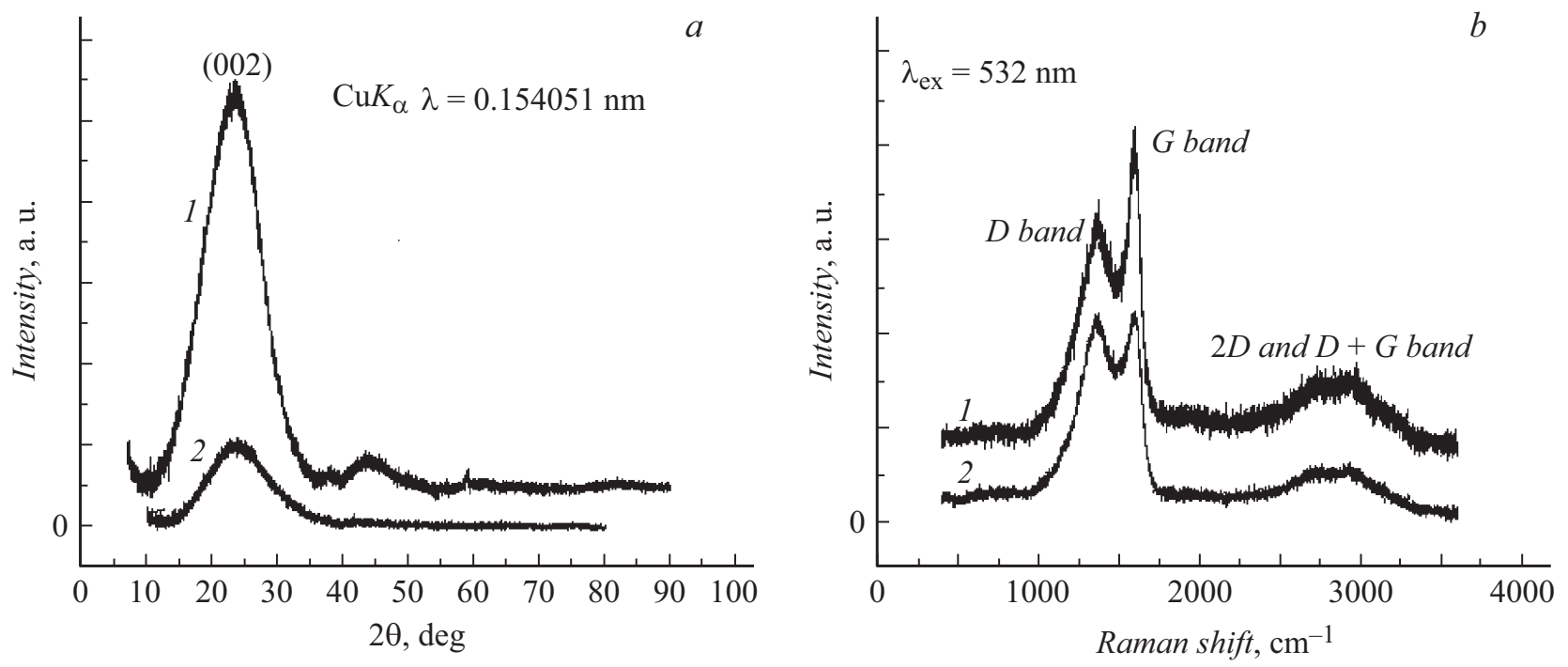

Рис. 2. Рентгеновская дифрактограмма $(a)$ и СКР спектр $(b)$ графеновых структур, синтезированных методом СВС: $1-$ из лигнина, 2 - из крахмала.

таких рамеров синтезированные частицы смогут вмещать значительное число микроорганизмов. Такой вид частиц характерен для $2 D$-углеродных структур (см., например, [16]).

Для оценки поверхностных свойств синтезированных графеновых наноструктур была измерена удельная поверхность образцов. Было установлено, что удельная поверхность образцов из лигнина и крахмала составила 525 и $410 \mathrm{~m}^{2} / \mathrm{g}$ соответственно, что позволит обеспечить высокую концентрацию клеток в малом объеме материала.

Для оценки качества синтезированных структур были проведены исследования методом рентгеновской ди- фракции, а также методом СКР, результаты которых представлены на рис. 2.

Как видно из рис. 2, $a$ на дифрактограммах синтезированных образцов гало в области $10-35^{\circ} \mathrm{C}$, типичное для малослойных графеновых структур [17]. Отсутствие узких и высокоинтенсивных графитовых пиков [18] позволяет исключить образование в ходе СВС процесса графита. Исходя из данных о положении и ширине пика (002) были определены межплоскостные расстояния для образцов графеновых структур, синтезированных из лигнина и крахмала, которые составили 3.74 и $3.85 \AA$ соответственно. Также была проведена оценка количества слоев в синтезированных графеновых структурах по формуле $N=(L+d) / d$, где $N-$ количество слоев, $L-$ 

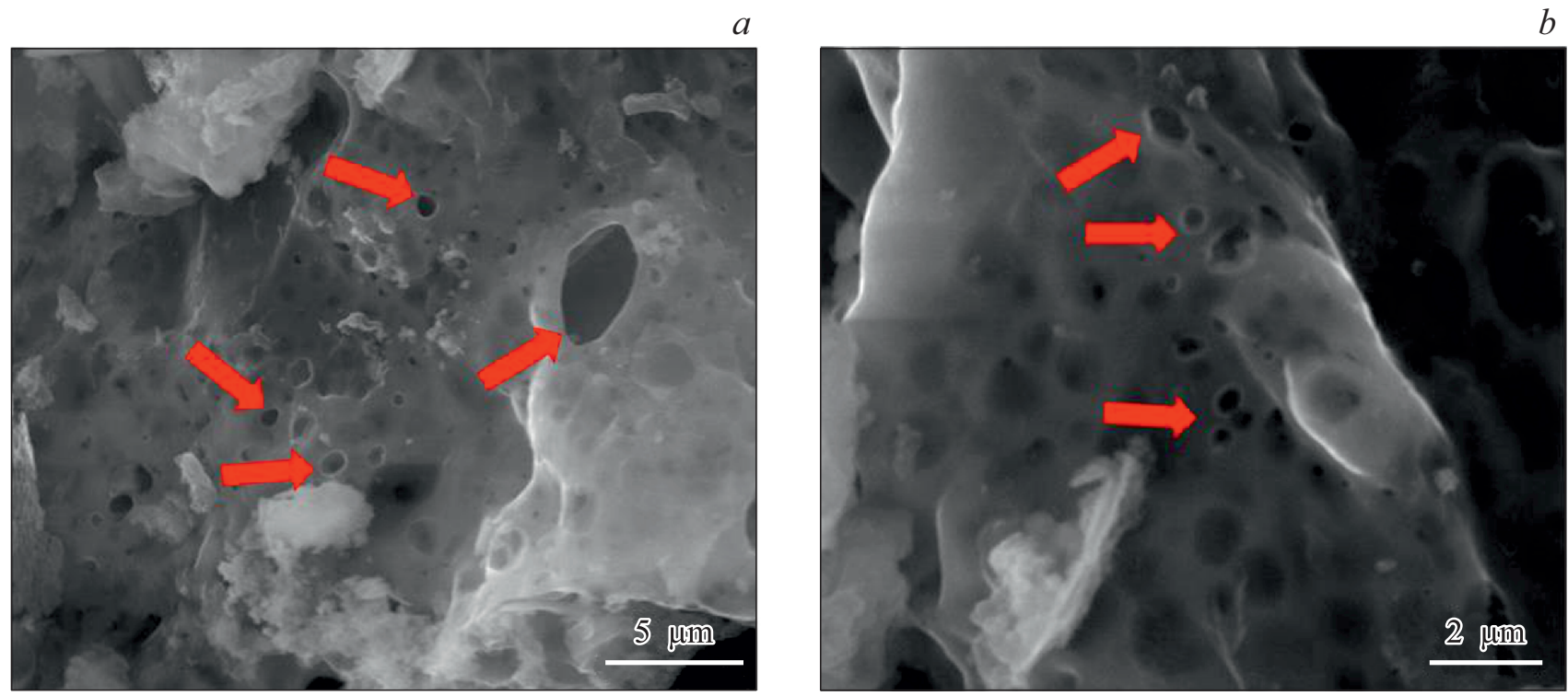

$c$

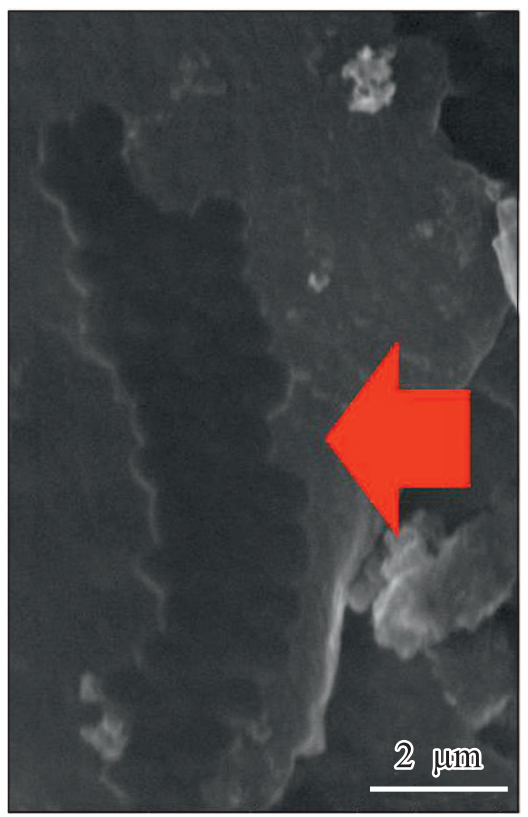

Рис. 3. Электронные микрофотографии графеновых структур, синтезированных методом СВС с иммобилизованными микроорганизмами (Rhodococcus rhodochrous ВКПМ AC-1016): $a$ - из лигнина, $b-$ из крахмала, $c$ - из лигнина. Стрелками отмечены микроорганизмы.

толщина пачки графеновой структуры, $d-$ межплоскостное расстояние [19]. Толщина пачки синтезированных графеновых структур была рассчитана по формуле Шеррера [20]. В результате расчета было установлено, что количество слоев в синтезированных графеновых структурах не превышает 5 .

Как видно из рис. 2, $b$ полученные спектры КРС имеют ярко выраженные высокоинтенсивные полосы $D\left(1345 \mathrm{~cm}^{-1}\right), G\left(590 \mathrm{~cm}^{-1}\right)$ и $2 D / 2 D+G$-область $\left(2500-3300 \mathrm{~cm}^{-1}\right)$. Соотношение пиковых интенсивностей $D$ - и $G$-полос для образцов, синтезированных из лигнина и крахмала, составляет 0.84 и 0.98 соответствен- но. В работе [21], где наблюдался аналогичный СКР для образца малослойного графена, полученного методом CBC путем пропускания диоксида углерода над порошком магния, авторы связали высокую интенсивность $D$ полосы, а также большую ширину области $2 D / 2 D+G$ с волнообразной структурой образцов, наличием большого количества кромок, а также разнонаправленным наложением графеновых слоев друг на друга.

Для получения информации о иммобилизации микроорганизмов на синтезированных графеновых структурах были проведены дополнительные СЭМ исследования, представленные на рис. 3 . 

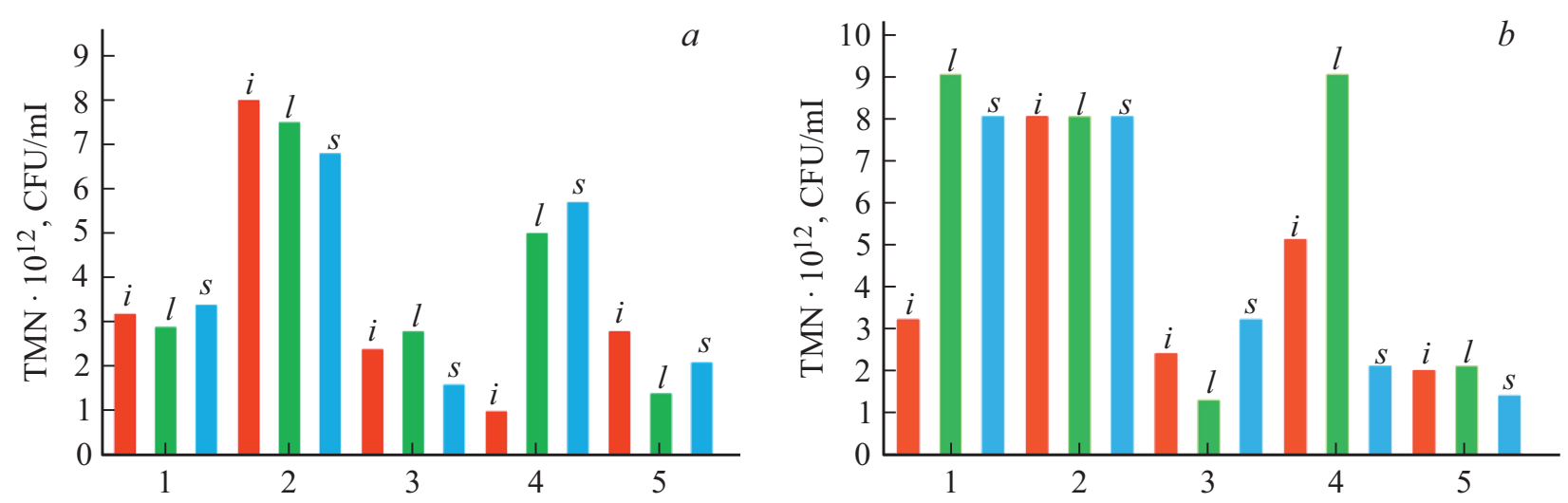

Рис. 4. Выживаемость культур микроорганизмов $(\mathrm{CFU} / \mathrm{ml})$ на графеновых нанопластинах (ГНП), полученных из лигнина $(l)$ и крахмала $(s)$ через 3 месяца хранения по сравнению с исходным титром (i). a - Serratia sp. Ант 1-1 (1), Nocardioides sp. Ко-1 (2), Paenibacillus polymyxa Kr ВКПМ B-4217 (3), Candida sp. R-2 (4), Acinetobacter lwofii PP-2 (5); b - Rhodococcus erythopolis ВКПМ АC-1269 (1), Rhodococcus rhodochrous ВКПМ AC-1016 (2), Pseudomonas fluorescens biovar II Aнт 10-1 (3), Burkholderia caryophilli Ант 14-2 (4), Brevibacterium sp. PР-7 (5).
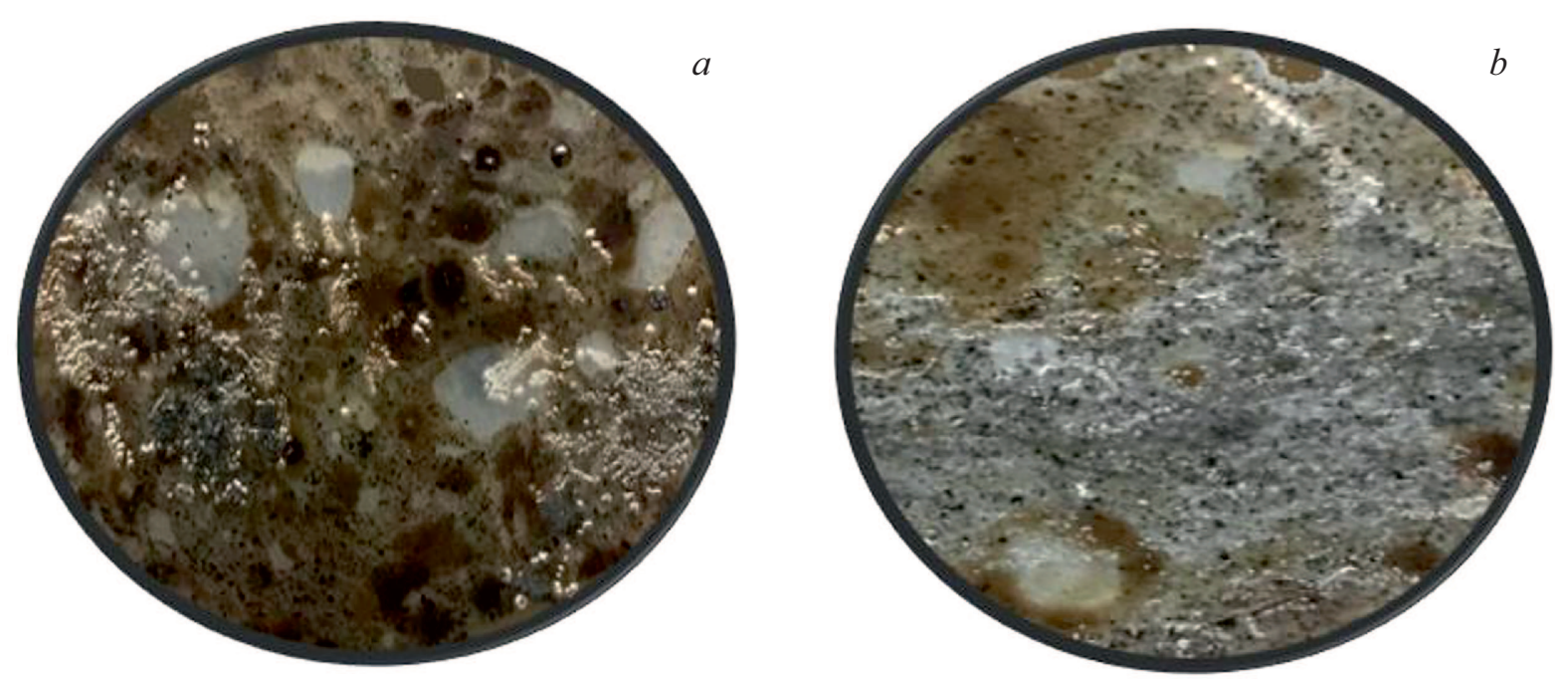

Рис. 5. Рост культур микроорганизмов-деструкторов углеводородов и нефтепродуктов (Rhodococcus rhodochrous ВКПМ АC-1016) на поверхности агаризованной питательной среды с нефтью в качестве единственного источника углерода: $a-$ исходный образец, $b$ - через $72 \mathrm{~h}$.

На рис. 3 видно, что микроорганизмы располагаются на листах графеновых структур и в отдельных случаях образуют колонии.

Следующая ступень к созданию биопрепарата на основе графеновой наноматрицы - оценка выживаемости культур микроорганизмов в ассоциации с синтезированным наноуглеродным материалом (рис. 4). В качестве тест-объектов в данных экспериментах использовали следующие культуры микроорганизмов: it Burkhordelia cariophylli, Streptomyces imbricatus, Streptomyces loidensis, Bacillus subtilis, Paenibacillus polymyxa, Pseudomonas fluorescens. Выбор этих культур в качестве тест-объектов обусловлен показанной их высокой активностью при использовании в качестве нефтедеструкторов.
Как видно из рис. 4 концентрация практически всех исследуемых штаммов микроорганизмов после трех месяцев хранения либо увеличилась, либо сравнима с концентрацией исходного титра, что доказывает высокую степень выживаемости микроорганизмов на синтезированных графеновых структурах.

На рис. 5 представлен пример лабораторного испытания эффективности графеновых структур с иммобилизированными микроорганизмами нефтедеструкторами (Rhodococcus rhodochrous ВКПМ АС-1016).

Рис. 5 позволяет судить о том, что нанесение полученного в результате работы биопрепарата приводит к резкому уменьшению загрязненной поверхности уже через $72 \mathrm{~h}$ (регистрируется по росту светлых областей просветленных от нефтепродуктов зон). Полученные 
данные также свидетельствуют, что графен отрицательно повлиял на нефтеокисляющую активность только одного штамма - Candida sp. R-2. Напротив, у целого ряда изученных штаммов - деструкторов - эффективность нефтеокисления или существенно повысилась, или осталась без изменения. Полученные результаты позволяют положительно оценить перспективы создания принципиально новых препаративных форм, ассоциатов активных отселектированных штаммов нефтеокисляющих микроорганизмов и графеновых листов.

\section{Заключение}

Результаты наших экспериментов позволили впервые экспериментально продемонстрировать, что использование процесса СВC позволяет получать $2 D$-углеродные структуры (графеновые структуры), пригодные для иммобилизованных широкого круга микроорганизмов. В полученных иммобилизованных биопрепаратах большинство штаммов микроорганизмов-нефтедеструкторов продемонстрировало высокую выживаемость, сравнимую или выше, чем у исходного титра. За счет развитой поверхности ГНП микроорганизмы иммобилизовались как в виде отдельных клеток, так и в виде колоний, что обеспечило высокую концентрацию клеток в малом объеме.

Было экспериментально показано, что полученные препараты могут применяться для решения важной экологической проблемы - эффективной очистки почв от нефтяных загрязнений,

Использование дешевых реагентов в совокупности с простым техническим исполнением СВС процесса позволит судить о реальности использования полученных по предложенной методике $2 D$-графеновых структур для получения иммобилизованных биопрепаратов в необходимом для реальной практики количестве и по доступной цене.

\section{Финансирование работы}

Работа Возняковского А.П. и Неверовской А.Ю. выполнена в рамках работ по выполнению гранта РФФИ № 18-29-24129 МК.

Работа Возняковского А.А. выполнена в рамках государственных тематических исследований ФТИ им. А.Ф. Иоффе по теме № 0040-2014-0013.

\section{Конфликт интересов}

Авторы заявляют, что у них нет конфликта интересов.

\section{Список литературы}

[1] Komarov I.A., Struchkov N.S., Antipova O.M., Kalinnikov A.N., Shcherbin S.N. // J. Phys.: Conf. Ser. 2019. Vol. 1410 (012064). P. 1-6.

DOI: $10.1088 / 1742-6596 / 1410 / 1 / 012064$
[2] Byun J. // J. Microbiol. Biotechnol. 2015. Vol. 25. N 2. P. 145-151. DOI: $10.4014 /$ jmb.1412.12045

[3] Shen H., Zhang L., Liu M., Zhang Z. // Theranostics. 2012. Vol. 2. N 3. P. $283-294$. DOI: $10.7150 /$ thno. 3642

[4] Um J.G., Jun Y.S., Alhumade H., Krithivasan H., Lui G., Yu A. // RSC Adv. 2018. Vol. 8. N 31. P. 17091-17100. DOI:10.1039/C8RA02087F

[5] Skoronski E., Souza D.H., Ely C., Broilo F., Fernandes M., Junior A.F., Ghislandi M.G. // Int. J. Biol. Macromol. 2017. Vol. 99. P. 121-127. DOI: 10.1016/j.ijbiomac.2017.02.076

[6] Foo M.E., Gopinath S.C.B. // Biomed. Pharmacother. 2017. Vol. 94. P. 354-361. DOI: 10.1016/j.biopha.2017.07.122

[7] Ying Wang, Zhaohui Li, Jun Wang, Jinghong Li, Yuehe Lin // Trends in Biotechnology. 2011. Vol. 29. N 5. P. 205-212. DOI: j.tibtech.2011.01.008

[8] Eletskii A.V., Iskandarova I.M., Knizhnik A.A., Krasikov D.N. // Phys. Usp. 2011 Vol. 54. P. 227-258. DOI:10.3367/UFNe.0181.201103a.0233

[9] Volkova I.A.B., Rezchikova E.V., Shakhnov V.A. // Eng. J. Sci. Innovation. 2013. Vol. 18. N 6. P. 1-11. DOI:10.18698/2308-6033-2013-6-807

[10] Yadav N., Dubey A., Shukla S., Saini C.P., Gupta G., Priyadarshini R., Lochab B. // ACS Omega. 2017. Vol. 2. N 7. P. 3070-3082. DOI: 10.1021/acsomega.7b00371

[11] Karahan H.E., Wiraja C., Xu C., Wei J., Wang Y., Wang L., Liu F., Chen Y. // Adv. Healthcare Mater. 2018. Vol. 7. N 13. P. $1-18$. DOI: $10.1002 /$ adhm.201701406

[12] Reshetilov A.N., Plekhanova Y.V., Tarasov S.E., Arlyapov V.A., Kolesov V.V., Gutorov M.A., Gotovtsev P.M., Vasilov R.G. // Appl. Biochem. Microbiol. 2017. Vol. 53. N 1. P. 123-129. DOI:10.1134/S0003683817010161

[13] Kovalenko G.A. Perminova L.V., Chernyak E.I., Sapunova L.I. // Appl. Biochem. Microbiol. 2010. Vol. 46. N 7. P. 697-705. DOI: $10.1134 / \mathrm{S} 0003683810070045$

[14] Voznyakovskii A.P., Savkin D.I., Kalinin A.V., Shugalei I.V., Krutov S.M., Mazur A.S. // Экологическая химия. 2016. T. 25. № 3. C. 132-137. [Voznyakovskii A.P., Savkin D.I., Kalinin A.V., Shugalei I.V., Krutov S.M., Mazur A.S. // Russ. J. Gen. Chem. 2016. Vol. 86. N 13. P. 3008-3011. DOI:10.1134/S1070363216130132]

[15] Сычев А.Е., Мержсанов А.Г. // Успехи химии. 2004. Т. 73. № 2. C. 157-170. [Sytschev A.E., Merzhanov A.G. // Russ. Chem. Rev. 2004. Vol. 73. N 2. P. 147-159. DOI:10.1070/RC2004v073n02ABEH000837]

[16] Fan Z., Wang K., Wei T., Yan J., Song L., Shao B. // Carbon. 2010. Vol. 48. N 5. P. $1686-1689$. DOI:10.1016/j.carbon.2009.12.063

[17] Akbar F., Kolahdouz M. // J. Mater. Sci.: Mater. Electron. 2015. Vol. 26. N 7. P. 4347-4379. DOI: $10.1007 / \mathrm{s} 10854-015-2725-9$

[18] Ghanem A., Abdel Rehim M. // Biomedicines. 2018. Vol. 6. N 2. P. $63-78$. DOI: $10.3390 /$ biomedicines 6020063

[19] Sysoev V.I., Fedorovskaya E.O., Senkovskiy B.V., Bulusheva L.G. // Phys. Stat. Sol. Basic Res. 2015. Vol. 253. P. 2492-2498. DOI: $10.1002 /$ pssb.201552299

[20] Patterson A.L. // Phys. Rev. 1939. Vol. 56. P. 978. DOI:10.1103/PhysRev.56.978

[21] Li C., Zhang X., Wang K., Sun X., Liu G., Li J., Tian H., Li J., Ma Y. // Adv. Mater. 2017. Vol. 29. N 7. P. 1604690-1604698. DOI: $10.1002 /$ adma.201604690 